\title{
Autumns Brave Show
}

By L. T. Carmichael

The advent of spring each year brings with it nature's favorite color, green. The slender blades of grass on the meadows and roadsides, the unfolding buds on the trees and shrubs; the tender foliage of awakening flowers, are heralds of another season, hopes of better things to come.

We love the green in all its myriad shades and hues. It is a color of which the eye never tires-Mother Nature has seen to that.

But when autumn days roll around, the foliage of our trees and shrubs, as if envious of the admiration accorded to brighter hues, bursts forth itself in flashing attire of red and gold and purple. It is not the swan's song of death but a gala farewell to summer; a joyful reminder that life persists and that after a period of rest it will awaken again in all its verdant splendor.

The autumn colors of the west may show nothing so brilliant as the flaming sugar maple or blazing sumac of the east, yet a drive along the Wascana or Qu'Appelle valleys will now display a vista of blending and contrasting colors unequalled anywhere.

There, one will see clumps of the pure gold of the trembling aspen, backed by the still dark green of the black poplar and shining leaves of the willow. The pin-cherries dressed in crimson; the maroon of the elder; the red and purplish tinge of the rose bush, all blend in with the yellows and browns of the smaller shrubs. Over in the hollow the bronze leaves of the green ash are shining in the sunlight as they flutter noiselessly to the ground and settle among the flaming scarlet of the poison ivy. Here, too, one may see the white-limbed birches, standing like nymphs in the shower of their own golden hair.

Yet one need not leave the city to admire these changes in nature. The northwestern poplar, the ash, the Manitoba maple and the elm are a blaze of glory showering leaves around the heads of pedestrians and carelessly dropping their shining gold pieces into the gutters at their feet. What is more brilliant than the crimson of the virginia creeper, the dark red of the cotoneaster or the mixed reds, yellows and greens of the Ginnala maple.

What is the real reason for all this display of splendor? How do the trees part with their leaves on the approach of winter? Deciduous trees and shrubs prepare to drop their folige by forming a layer of hard-walled cork cells at the base of each leaf. This layer serves to cut off the leaf from the twig or branch on which it grows. Before this layer of cells is formed, most of the food and living substance of the leaf is drawn into the other parts of the piant. Chlorophyll, the vital green granules of the leaf, disappears, making way for the latent yellows and reds.

We hear much of the work of Jack Frost as he paints the leaves of September and October, yet frost has nothing to do with the change in color. In fact, after a sharp frost, the leaves will wither and die and fall to the ground without beauty or tint. On the other hand, as light is necessary to implant an image on a photographic plate, so is it essential to the production of reds and purples. Continucus cloudy weather will destroy the display while an average amount of moisture and sunny autumn days will dress up the trees in all their glory.

Three chemicals, embedded within the cells of the leaf, are responsible for the fall tints. The basic one is xanthophyll, the same true dye that is found in the yolk of an egg. This is entrenched deep in the cells of the spongy layer and gives rise to most of the yellows. It is affected very little by sunlight. These pigments are always present in the cells, but are masked from our sight all summer by the rich green of the chlorophyll. Many leaves, such as the waxy broad ones of the northwestern poplar, the elm and the aspen, contain no other pigment after the disappearance of green.

The reds and purples are due to anthrocyanins, water-soluble stains found only in the outer cells of cer- 
tain leaves. Just as acids turn litmus paper red, so sunlight brings out this color on the surface of the leaf. Often the yellow below will shine through the red at the surface, painting it a brilliant orange. The part of a maple leaf, overlapped by another one, will be yellow while the exposed portion will become a study in shades of crimson. The brown color in leaves is due to the presence of tannin. This dye, coupled with the yellow of xanthophyll, gives our green ash its blending shade of bronze and gold.

Poor rocky acid soils are conducive to bright colors of red and orange. The acids assist the sunlight in bringing to view the latent hues of the anthrocyanins. Sugar in sap is another factor especially inductive to reds. The king of autumn foliage is the sugar maple of the east and a close runner-up is the Ginnala maple which grows on Regina lawns.

It has often been stated that it is essentially death that causes all this brave show, but to the writer it is not goodbye but au revoir.

\section{Routes of Migration Change \\ Arthur Ward}

FTEN we look back over the years and wonder why certain species of birds change their route of migration. During the Twenties, the Black-billed Cuckoo never failed to stay with us. Two of these were banded in the year 1926. The Cliff Swallow, too, often dallied around. When the P.F.R.A. Highfield Dam was under construction, one of the towers was very thickly plastered with nests of a colony of these birds, built during the noise of the accompaning traffic. The foreman told me afterwards that their persistance finally gave way to the constant vibration of the passing vehicles. They departed and never returned.

On the other hand we have noticed the presence of the Fox Sparrow being mentioned in the BLUE JAY as a frequent visitor in some districts. During the time of our stay in the Swift Current district, we have never seen a Fox Sparrow.

\section{October}

By Allen E. Woodall

What can we ask more than a day

That sets goid leaves against the gray

Of rain worn walls, or on a sky

Bluer than lakes where white gulls cry,

And calls the yellow sunlight through

Thin branches groping for the blue.
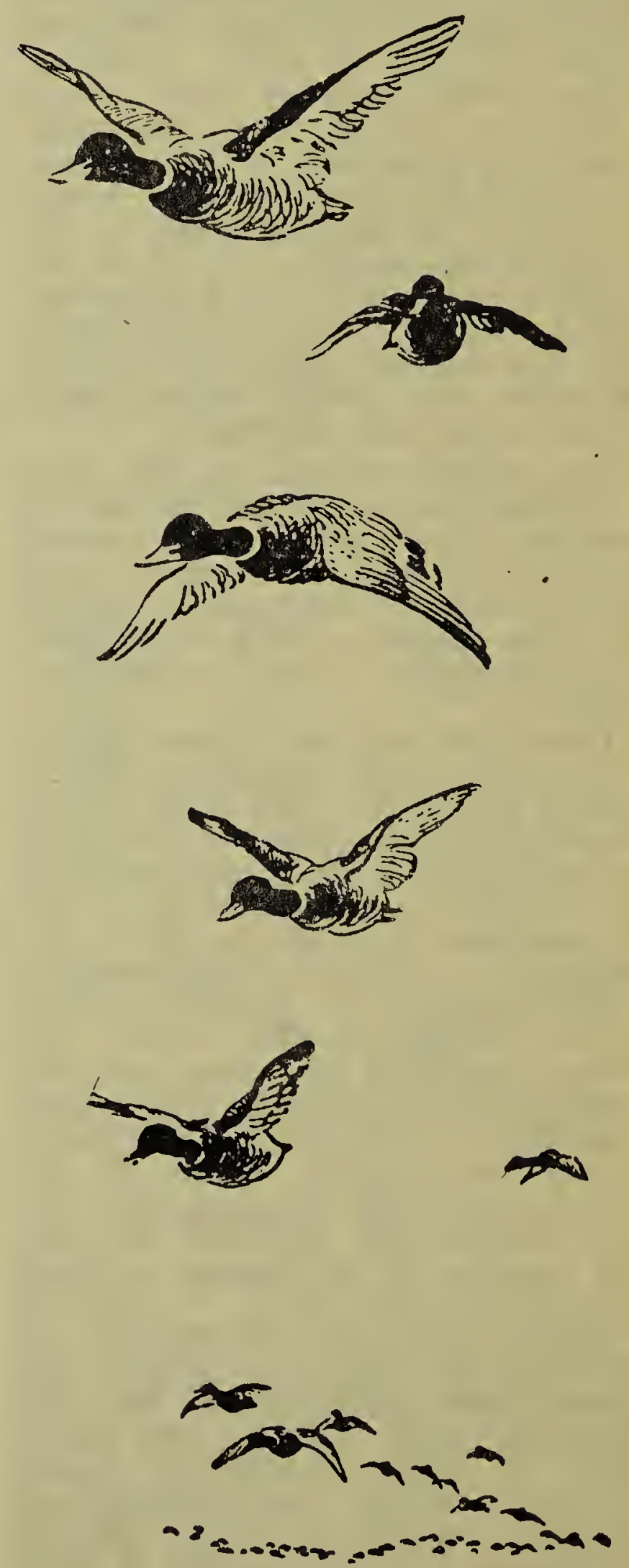